\title{
The European Community as an Agent of Reform: EC Admission Criteria and Romania
}

\author{
Steven D. Roper, University of Missouri, Columbia
}

This analysis examines the role of the European Community in the transition to democracy and a market economy in Romania. Specifically, the EC admission criteria developed during the second enlargement (viz., the democratic reform of, economic transformation of, and foreign policy of applicant states) are applied to a case study of Romania in order to understand why Romania was offered associate membership in the EC. It is found that both EC and Romanian officials see Romania's associate membership as a vehicle for further political and economic reform within that country. An implication is that the EC may view further Southeastern enlargement as a hedge against instability in the region.

There is a great deal of debate concerning the admission of East European countries into the European Community (Angelis 1991; de Weydenthal 1992; Sobell 1991). It is assumed that the East Central European countries such as Poland and Hungary have the best prospect of gaining full admission to the EC (Roskin 1991; Griffith 1989, 8). The implicit assumption is that the Southeast European countries offer the least possibility for full admission into the EC. Most of the literature, therefore, has neglected to examine the possibility of Romanian or Bulgarian admission. However on 1 February 1993, Romania became the fourth East European country to sign an association agreement with the EC. ${ }^{1}$ Some observers of East and West European politics may be surprised by the speed with which Romania has attained an association agreement. In order to understand the admission of any East European country, we must first understand the admission criteria of the EC.

In the first section of this paper, I shall examine the admission criteria of the EC during the so-called second enlargement (the admission of Greece, Spain and Portugal). The criteria shall be examined from three perspectives: the process of democratization, agricultural and industrial development, and foreign policy. By examining the EC admission criteria from these perspectives, we are able to understand the EC's role as an agent of reform in East Europe. Some might question the role of the EC following the Maastricht votes. While Denmark eventually opted for monetary union, the referenda showed how vulnerable the process of integration can be. The EC process

STEVEn D. ROPER is ABD in Political Science at the University of Missouri. Columbia.

The American Review of Politics, Vol. 15, Spring, 1994: 105-121

(\$) 1994 The American Review of Politics 
of re-examination should not be viewed as the end of the EC as an institution or agent of reform. Rather, the Maastricht votes represent a normal process of integration. Indeed, formal integration by definition is a discontinuous process (Wallace 1990, 53-67). The Maastricht votes do not diminish the role of the EC in shaping the institutions of East Europe, nor do they appreciably change the EC admission criteria.

We can note two aspects of these admission criteria. First, the EC admission criteria are a combination of both formal and informal principles. A formal principle is denoted by specific reference either to a treaty or an agreement. An informal principle very well might be applied to all applicant states; however, it is a principle that is not specifically enunciated in any formal declaration. Second, during the second enlargement, the criteria used by the individual EC member states differed substantially. For some EC members, greater emphasis was placed on the issue of democratization, and for other EC members, greater emphasis was placed on economic integration.

In the second section, I shall apply these criteria to a case study of Romania. While applying these criteria to any East European country has certain limitations, such criteria are especially suited for an analysis of Romania. These criteria are based upon countries that form part of Southern Europe, are recent democracies, and have semi-industrial economic development. Based on the criteria developed here, we gain a greater appreciation of why Romania was offered an association agreement. By examining the EC admission criteria developed during the second enlargement, we find that the association agreement signed by Romania actually is not a surprising outcome.

\section{EC Admission Criteria: The Process of Democratization}

While economic and foreign policy issues were part of the EC admission criteria to admit Greece, Spain and Portugal, perhaps no issue was as important as the democratization of Southern Europe. ${ }^{2}$ The last passage of the Preamble to the Treaty of Rome states that the member countries are "calling upon the other peoples of Europe who share their ideal to join in their efforts" (Schloh 1980, 393). This "ideal" is described in greater detail, in the Preamble to the Statute of the Council of Europe, as "reaffirming their devotion to the spiritual and moral values which are the common heritage of their peoples and the true source of individual freedom, political liberty and the rule of law, principles which form the basis of all genuine democracy" (Schloh 1980, 394). While the Council of Europe is not part of the EC, its principles reflect the same concerns as articulated in the various 
EC Commission Opinions. As part of these formal principles, the applicant state must be democratic and extend fundamental human rights.

The EC maintains that applicant countries must present both substantive as well as procedural democracy. Theorists such as Barber (1984), Dahl (1970) and Macpherson (1977) have defined substantive democracy as participatory politics which guarantee fundamental human and political rights. Substantive democracy emphasizes greater political and social participation of the entire citizenry and de-emphasizes the role of institutions. However, others, such as Schumpeter (1943) and Oppenheim (1971), have defined democracy as essentially an electoral procedure. Schumpeter writes that democracy is a "political method, that is to say, a certain institutional arrangement for arriving at political . . . decisions" (1943, 241). According to Oppenheim (1971), the policy enacted by the government does not matter as long the government is following the electoral and institutional "rules of the game."

While the principles of democracy were an important part of the admission criteria during the second enlargement, there actually was very little discussion on the part of the EC member states as to the specific elements of substantive or procedural democracy. Moreover, there was little discussion of whether the applicant countries conformed to this democratic ideal. Did Greece or Spain have a genuine democracy that extended fundamental human rights to all citizens? Did Portugal have procedures that ensured fair elections? The answer of the EC simply was to assume that each applicant country had achieved a certain level of both substantive and procedural democracy. ${ }^{3}$

While the EC acknowledged that the three applicant countries were democratic, the EC also recognized that these were fragile democracies. In each instance, it was argued by the applicant state, as well as the EC, that the Community would provide stability to the democratic political process within the country (Mulligan 1977; Redston 1983; Pesmazoglu 1977). Pollis $(1983,209)$ argues that "the most forceful justification for incorporation of the three in the EC . . a a rationale articulated both by the Council of Ministers and by the governments of the three countries, is that membership in the EC will ensure the survival of parliamentary democracy [and] increase political stability." The argument was advanced that it would be much more difficult to overthrow the democratic governments of the three applicants countries if they were part of the EC.

The EC recognized that it could be an agent for democratic reform only if membership was supported by the majority of the political parties and the population. Therefore, as part of the admission process, the EC also considered the desire for membership among political parties and citizens of the 
three applicant countries. The EC supported the membership of Greece, Spain and Portugal because there was widespread party and public support within each country for membership. In Greece, for example, 80 percent of the electorate favored full EC membership (Pesmazoglu 1977, 7). In Spain, EC membership was supported by virtually all political forces, including King Juan Carlos I, Premier Adolfo Suarez, Socialist Workers' Party head Felipe Gonzalez, and even Spanish Communist Party head Santiago Carrillo. When President Soares of Portugal tendered his country's application he stated that EC membership was supported by a solidarity of people in Portugal. The EC Commission Opinions repeatedly pointed to the indigenous political support found within each of the applicant countries for membership.

During the second enlargement, the issue of democratization was based on the premise that the EC can provide support and stability to democratic institutions in Europe-even though the EC had yet to specify what constitutes democracy, or what is the best method for supporting democracy. It was assumed both by the EC and the applicant states that a vibrant economy was one of the best supports for a fledgling democracy.

\section{EC Admission: Agricultural and Industrial Development}

While I have noted that the second enlargement dealt extensively with the political structures of the applicant states, it certainly did not exclude economic issues. As Schloh $(1980,395)$ notes, however, "whether a 'free market economy' is also a condition [for EC membership] may be a more difficult question to answer." The Treaty of Rome contains a clause that sheds some light on the EC admission process. Article 3(c) of the Treaty guarantees the free movement of labor among member states. Furthermore, the Treaty maintains that "member states may no longer (except in the public service) discriminate against citizens of other Community member states by giving priority for a job to one of their own citizens" (Granell 1978, 69). Several Community members, most notably France and Germany, were concerned about an exodus of workers from Greece, Spain and Portugal. France argued that the high unemployment rates of the three applicant states made the free movement of labor within the EC problematic. Thus, while free labor movement is a guarantee of the Treaty of Rome, during the second enlargement, it also became part of the admission calculus (Swann 1984, 160-163).

The greatest economic concern of the EC member states, and also the most important, was the structure of the economies of Greece, Spain and 
Portugal, respectively. Specifically, the EC members were concerned about the high percentage of labor force engaged in agriculture in the three applicant states. Not only was a substantial amount of the labor force engaged in agriculture, the structure of agriculture itself was largely inefficient. In addition, the EC Commission was concerned about the structural imbalance in the economies of the three applicant countries. For instance, in the case of Greece, the EC Commission was concerned that the Greek economy had a number of structural features that limited its ability to integrate the economies of the $\mathrm{EC}$ member states (Bulletin of the European Communities 1976, 8).

This sentiment also was expressed in the cases of Portugal and, to a lesser extent, Spain. Like Greece, these countries had a high percentage of their labor force engaged in agriculture, and excluding Spain, the industries of the applicant states were undercapitalized and not diversified. Redston $(1983,210)$ notes that "the principal weakness of Portugal's industry is that it is dominated by sectors at present suffering from overproduction in most parts of the world." The problem in all three countries was that the economic sectors relied upon labor-intensive industries (Smith and Wanke 1993).

Thus, the EC was concerned not only about the percentage of the labor force engaged in agriculture, but also about the nascent industries of the three applicants, especially Greece and Portugal. Certain EC member states, most notably France and Italy, also were concerned about the impact that the second enlargement would have on their own agricultural industries and the CAP (Common Agricultural Policy). France especially was concerned about the accession of Spain into the EC. France was worried that the second enlargement would affect its agricultural markets, and therefore France requested changes in the EC's CAP (Mulligan 1977, 4).

A final economic issue considered was the actual effect of an enlarged membership on the EC in terms of the dispersal of aid and the budget. Less developed members of the EC would vote for expansion only if there was a guarantee that they would lose no aid to the Mediterranean countries. For example, Ireland was afraid that it might lose many of the cash benefits it had enjoyed from EC membership (Mulligan 1977, 6). Member states actually began to demand increases in aid in exchange for voting for EC enlargement. An interesting case involved Greece. By the mid-1980s, Greece was demanding increases in the Integrated Mediterranean Program (a southern aid program) in exchange for voting for the accession of Spain and Portugal.

In terms of the budget, the EC member states concluded that the admission of the three Mediterranean applicants would not adversely affect 
the EC budget. Based upon a computer simulation requested by the Commission, the EC concluded that the impact of Spain and Portugal on the 1980 EC budget would have been minimal and that the cost to the EC of admitting these two countries was not prohibitive. Thus, as Redston $(1982,212)$ argues, "the low cost of membership . . . strengthens the case for an early conclusion to the membership negotiations."

While political issues dominated the admission criteria of the EC, certainly economic factors were an important part of the overall EC criteria. There were both structural and capital problems which the second enlargement presented; however, in the end, the EC concluded that the costs were low and that integrating these fledgling democracies was a political necessity.

\section{EC Admission: Foreign Policy}

The final element of the EC admission criteria that shall be explored concerns the foreign policies of the three applicant countries. The EC association agreements became the conduit for foreign relations. Countries that have association agreements with the EC have to maintain a stable and non-interventionist foreign policy in order to maintain the agreement. If these countries engage in foreign policies that the EC regards as counterproductive, then the EC unilaterally will suspend the agreement.

During the second enlargement, the foreign policy of Greece figured significantly in the EC admission process. The EC was concerned that it would become inextricably involved in the dispute between Greece and Turkey. ${ }^{5}$ This was complicated further by the fact that the EC had signed an association agreement with Turkey in 1963. The EC was concerned that Greece's new status as a full member would threaten the balance of relations between Greece and Turkey. "Until now the balance in the Community's relations with Greece and Turkey has found its expression in their identical status as Associates .... . the prospect of Greek membership in the Community introduces a new element in this balance" (Bulletin of the European Communities 1976, 8).

During the second enlargement, foreign policy concerns vis-à-vis Greece and Turkey centered upon maintaining the status quo. Therefore, EC membership was not seen as a vehicle for greater stability in the Mediterranean but instead as a possible impetus for conflict. The EC attempted to ensure that membership would not have a detrimental effect upon foreign relations within the Mediterranean. 


\section{EC Admission Criteria and Romania: A Case Study}

There are obvious differences between Romania and the countries of the second enlargement. Even though this exercise will yield interesting comparisons and contrasts, two caveats should be made. First, although Greece, Spain, Portugal and Romania all labored under oppressive political regimes, there were substantial political, economic and foreign policy differences between these countries. Certainly Romania's communist past and current attempts to deal with that past make any comparison with the countries of the second enlargement more difficult.

Second, the political and economic environments of the EC have changed dramatically since the second enlargement. The fall of communism in late 1989 has created a host of countries vying for membership in the EC. Currently, there are more than ten countries either in the process of preparing an application or actually applying for membership in the EC. ${ }^{6}$ Thus, the new political environment in which Romania finds itself has had an impact on the process of EC membership.

\section{Romania and the Process of Democratization}

As part of the EC's admission criteria, the applicant country must demonstrate a democratic political system that respects fundamental human and political rights and that ensures democratic electoral procedures. So for Romania, there are two important questions that must be answered. First, does Romania have a government that guarantees certain democratic procedures? Second, does the Romanian government respect substantive democratic rights, such as the right of free expression?

The best indicator of whether the Romanian government guarantees democratic procedures was the election of 27 September 1992. The overwhelming victory of President Ion Iliescu on both the first and second ballots ${ }^{7}$ and the unexpectedly mediocre showing of the Democratic Convention of Romania (DCR), an alliance of the country's main opposition parties, contributed to charges of voter fraud. These charges centered upon the large number of ballots that were nullified. The percentage of nullified ballots ranged from 4.65 percent for the presidency to 14.62 percent for the Chamber of Deputies. The Central Electoral Bureau maintained that the large number of nullified ballots was due to the complicated voting procedure, and indeed most international observers considered the election to be generally fair. Even some opposition leaders admitted that the election was lost because of policy rather than fraud. For example, Nicolae Manolescu, President of the Civic Alliance Party (PAC), stated that "we did not 
lose because of fraud . . . but because we were unable to convince the Romanian electorate that we were better than the others" (Shafir 1992a, 7).

What the elections of 1992 did accomplish was to alter significantly the balance of power within the parliament. Whereas the National Salvation Front (NSF) received approximately 66 percent of the seats in parliament in the 1990 election, the combined National Salvation Front and Democratic National Salvation Front (DNSF) ${ }^{8}$ received 38 percent of the seats in parliament in the 1992 election. What this outcome has meant is that opposition forces have become important political actors in the process of EC integration. From the perspective of the EC, and in terms of the national electoral procedures themselves and their outcome, Romania can be regarded as a country that has attained a reasonable level of procedural democracy. While there certainly was fraud in both the 1990 and 1992 national elections, the incidents of fraud were random and not viewed by Western observers as systematic.

While the national elections in Romania have been marred with some charges of fraud, the mayoral and county council elections in February, 1992 had virtually no incidents of fraud (Shafir 1992c). While the process of tabulating ballots was extremely slow, government and opposition leaders were satisfied that the electoral procedures were honest. As a result, DCR candidates won mayoral elections in some of Romania's largest cities, including Bucharest, Timisoara, Constanta, Brasov and Sibiu. Therefore, procedural democracy seems to have been achieved in Romanian local elections.

While the argument can be made that the Romanian government has achieved a satisfactory level of procedural democracy, there continually have been doubts about the level of substantive democracy in the country. It was the dearth of fundamental human and ethnic rights that alarmed the EC the most. On 14 June 1990, miners from the Jiu Valley entered Bucharest and, at the urging of the government, began to harass government opposition and beat student protesters in Bucharest square. As Shafir (1991, 36) notes, this incident greatly damaged the Iliescu government's image in the West, especially among EC members. However, since this episode, the Romanian government has made efforts to improve its human rights image abroad. These efforts have concentrated on two fronts: the drafting of a new constitution and human rights legislation.

The new Romanian constitution was approved in December, 1991. This constitution guarantees greater individual and group liberties, equal rights, and freedom of conscience. A provision was included in the constitution which stated that international legislation on human rights took precedence over domestic laws (Zidaru-Barbulescu 1993, 13). The constitution was not 
without its detractors; however, the new constitution was seen as a step in the right direction. Frits Hondius, the head of a Council of Europe delegation, stated that "Romania's Constitution will be the best that can be written" (Zidaru-Barbulescu 1993, 12).

The Romanian government also became involved in establishing human rights legislation. During 1990 and 1991, Romania signed the UN protocol on the abolition of the death penalty, and the UN convention on the prohibition of torture and inhumane treatment (Shafir 1992b, 14). Perhaps the greatest challenge ahead for Romania is the issue of minority rights. Although the Romanian government has stated on numerous occasions that minority rights are respected and that minority groups are represented in the parliament, ethnic clashes such as in Tirgu-Mures in March, 1990 show that Romania's minority problem is far from resolved. ${ }^{9}$

As part of the process of democratization, it earlier was noted that the EC was considered a guarantor of democracy. Both the EC and the applicant countries, such as Greece and Portugal, argued that EC membership would stabilize the nascent democracies of the Mediterranean. This proved to be an important part of the overall EC admission criteria. Because of recent legislative and electoral changes, Romania now is able to make this argument, and indeed Romanian officials did argue that membership in the EC would stabilize and protect Romanian democracy. In fact, "many observers believe that Romania's association with the EC will bolster democratization . . . in that country" (Ionescu 1993, 34). European Community membership is regarded by the Romanian government as a vehicle for Romanian political and social change. Napoleon Pop, Romanian State Secretary and head of the Department of European Integration, stated that the association agreement "offered Romania its only chance to break out of a political isolation rooted both in its communist past and in a number of developments since 1989" (Ionescu 1993, 34). Thus, the arguments made in the second enlargement concerning democratization are now being recycled by Romania, and it seems that this argument is still an important consideration in the EC admission process.

Another element of the process of democratization involves the support of EC membership by a broad coalition of political parties as well as citizens in the applicant state. During the second enlargement, domestic political support proved to be an important part of the overall EC criteria. The evidence indicates that EC membership is supported by a number of the Romanian political parties and a large percentage of the population. Opposition leaders such as Emil Constantinescu, the presidential candidate of the DCR in 1992, have voiced their support for the signing of the agreement. This is significant because the DCR is an alliance of the country's most 
important opposition parties, including the Hungarian Democratic Federation of Romania (HDFR). Ionescu points out that "the great majority of Romanians greeted the signing of the association agreements with approval" $(1993,37)$. In addition, many of the editorials in Romania's most important newspapers have supported the agreement. Adevarul, Romania's largest daily, immediately wrote in support of the agreement.

The improvements by the Romanian government in both procedural and substantive democracy have played an important role in the signing of the EC agreement. The support of political parties, the general public and, significantly, the Hungarian minority also have helped to bring about Romania's association agreement. The EC now can point to the need for supporting Romania's fledgling democracy - an argument that could not have been made two years ago.

\section{Romania and Agricultural and Industrial Development}

While Romania has instituted measures to improve human and minority rights since 1990, the economy has continued to have significant problems. Considering the poor performance of the Romanian economy, some might question why the EC would extend an association agreement to Romania. There certainly are facets of the Romanian economy that are attractive to the EC; however, these facets are off-set by a struggling and inefficient industrial sector and labor force.

East European countries such as Romania are moving slowly toward a capitalist, free market economy. The EC has defined a free market economy by stipulating terms and conditions as part of East European association agreements. Specifically, the Romanian government will have to allow greater foreign imports, increase the level of personal and corporate privatization, reduce subsidies to consumers, adopt bankruptcy laws and guarantee free repatriation of profits (Ionescu 1993, 35-36). Until this economic transition is complete, however, one is unsure how to describe the economies of East Europe. Specifically in the Romanian case, the economy is a combination of free market and command structures. In that respect, the Romanian economy shares certain attributes with the applicant countries of the second enlargement.

As previously mentioned, the free movement of labor was an important economic issue during the second enlargement. Currently, Romanian immigration is not an issue of concern within the EC. In fact, EC Commission Opinions regarding Romanian membership never addressed the issue of immigration, although Romanian immigration recently has become a concern of the German government. The deterioration of the Romanian economy and 
the opening of borders has caused Romanian immigration problems within East European countries, and since this situation is likely to get far worse, in the future the EC might focus more attention on immigration. Consequently, this issue may prove more divisive when Romania is considered for full membership.

During the second enlargement, the EC was concerned not only about immigration, but also about the balance of labor within the applicant country. As of 1987, 28.2 percent of the Romanian labor force was engaged in agriculture. This share was smaller than in Greece or Portugal before their accession into the EC. In fact, agriculture provided 15.9 percent of the national income for 1987 (The International Year Book 1990, 509). Therefore, the balance of labor within Romania does not differ significantly from that in the countries of the second enlargement.

The problem with the Romanian agricultural sector is that it is woefully antiquated, inefficient and unproductive. Romania, once the so-called "breadbasket" of Europe, has become a net food importer. During the first quarter of 1990 and throughout 1991 and 1992, food imports increased in terms of both value and volume (The International Year Book 1990, 509). Romanian exports fell by 45 percent in the first quarter of 1991 because of a reorientation in Romanian trade policy (Economic Bulletin for Europe 1991, 62). Under Ceausescu, foodstuffs were exported by Romania to pay off the national debt. This meant that there were reduced foodstuffs for domestic consumption. During 1990, Iliescu instituted a new government trading policy that re-routed these foodstuffs back into the domestic economy. Thus, the proportion of Romanian exports has fallen dramatically at the same time that Romanian imports have increased.

The argument could be made that the current Romanian reliance on Western food exports actually has aided the Romanian application to the EC. The Community currently faces a glut of food production, and the ability to re-direct this food surplus to Romania, particularly for Spain and Portugal, might have enhanced Romania's application. It will take years before Romanian agriculture recovers from the ill-conceived economic plans of Ceausescu. During that time, EC food-exports will be vital to feeding the Romanian population. Indeed, Prime Minister Vacaroiu recently requested that Romania be granted EC aid in the form of 250,000 tons of wheat (Ionescu 1993, 35). In the long term, however, this situation might change dramatically. Once the agricultural industry is reformed, the pre-conditions exist in Romania for it to become a net food exporter. Ironically, EC associate status itself might create the conditions necessary for Romania to become an agricultural threat to the various member states within the EC. Certainly, countries such as Spain, Greece, Italy, Portugal and France would 
not welcome additional agricultural competition. It would seem, therefore, that Romania's potential agricultural production very well may hinder its chances for full membership.

Romanian industrial production also has fallen sharply. During 1990, Romanian exports of manufactures, semi-manufactures and fuels all declined. In fact during the first quarter of 1990, Romanian exports of fuels declined by 50 percent. Its petrochemical industry has suffered severe production cuts, and thus Romania has begun to increase its importation of petroleum. In 1989, Romanian importation of Soviet crude oil amounted to 3.9 metric tons or approximately 700 million USD (The International Year Book 1990, 509). This is particularly alarming since the Romanian petrochemical industry was one of the most important foundations of Romanian trade policy. During the late 1960s and throughout most of the 1970s, Romania was a net exporter of energy, particularly crude oil and petroleum products.

There are signs, however, that indicate that this trend can be reversed. Foreign expertise and equipment could greatly enhance Romania's ability to recover petroleum deposits, especially from the Black Sea operations. State Secretary Pop stated that the association agreement would provide Romania "an influx of technology" (Ionescu 1993, 35). Estimates indicate that Romanian petroleum exports could reach 11 million tons with the addition of new equipment (Gorst 1990, 22). Thus, Romania offers to the EC an industry with a great deal of potential. Realizing the energy needs of the EC, the Romanian petrochemical industry might become a focus of EC trade and technology policy in the years to come.

Ultimately, the association agreement is viewed by Romanian officials as the impetus to restructuring the economy and instituting market reforms. In October 1993, Alain Mayhew, head of an EC delegation to Romania, pledged support for Romania's free market reforms and promised to aid Romania in its eventual application for full membership (Shafir 1993). The $\mathrm{EC}$ is seen in Romania as a positive and indispensable force in the move toward a market-oriented economy. State Secretary Pop stated that the agreement with the EC will assist "Romania's efforts . . . to complete the conversion from an over-centralized to a free market economy" (Ionescu $1993,35)$.

\section{Romania and Foreign Policy}

With the recent events in the former Yugoslavia, foreign policy and security issues have become extremely important within the EC. The admission of Romania reflects this interest in security issues. Jacques Delors, 
President of the European Commission, stated that Romania's association agreement would assist the country in becoming "a pole of stability" (Ionescu 1993, 33). Prime Minister Vacaroiu stated that Romania would become a stabilizing force in a region torn with ethnic violence. Except perhaps for the former Yugoslavia, Romania has had a foreign policy closer to the West than any other East European country. The association agreement that Romania signed in February, 1993 is similar to the association agreement signed by Greece as well as by the former Czechoslovakia, Hungary, and Poland. This type of agreement involves economic concessions and special trading relations and specifically prepares the non-member country for future accession into the EC. It is this agreement that becomes the conduit for foreign policy. As mentioned previously, the EC unilaterally can suspend the agreement because of an interventionist foreign policy.

Remington (1992) maintains that the search for security in East Europe is a product not only of ethnic and territorial concerns but also of a concern over the very structure of security in the region. The disbanding of the Warsaw Pact, the uncertain future of NATO, and the limited capabilities available within the WEU and the EC have made security and foreign policy a much more important consideration in the EC admission criteria. Overturf $(1992,27)$ argues that the civil war in the former Yugoslavia has demonstrated the "necessity for stability in the region."

Romania exists in a geographically and historically volatile situation. Romania has borders with the former Yugoslavia, Hungary, Bulgaria and Moldova. Each of these three countries represents a significant foreign policy and security problem. Perhaps the most salient aspect of Romanian foreign policy concerns Romanian relations with Hungary. Excluding the current situation in the former Yugoslavia, the debate between Romania and Hungary over the status of Transylvania remains the most dangerous territorial dispute within East Europe. The dispute centers on the Transylvanian lands that currently belong to Romania and from which there has been a flood of illegal immigration within the past decade.

Much like the Greek-Turkish dispute over Cyprus, the RomanianHungarian dispute over Transylvania easily could have become a matter for the EC. For example, if the EC had extended associate membership only to Hungary, this might have caused even further immigration from Transylvania. This in turn would have jeopardized the territorial integrity of Romania and possibly led to a border conflict between Romania and Hungary. However, by signing an association agreement with Romania, the EC has placed Romania on fairly equal grounds with Hungary. As previously mentioned, the EC was concerned during the second enlargement about the unequal status of Greece and Turkey. Delors stated that the association 
agreement indicated Romania's embrace of European unity-a unity presumably founded upon improved Romanian-Hungarian relations.

In addition to the Transylvanian situation, the hypothetical incorporation of Moldova into Romania looms as a potential foreign policy problem. The Council of Europe indicated that its decision to grant Romania membership involved a consideration of Moldova (Zidaru-Barbulescu 1993). Much of the territory in Moldova once was part of Romania. Individuals on both sides of the Prut River have called for the reunification of Moldova with Romania. President Iliescu has indicated that the Romanian government has no interest in pursuing reunification (Chinn and Roper 1993; Socor 1992). The Romanian and Moldovan governments signed a protocol in December, 1992 that recognized the independence of the two states (Monitorul Oficial al Romaniei 1992). However, the current violence in Moldova between the Russian minority and the Moldovan majority could spill over into Romania. Therefore, the EC agreement, which restricts the foreign policy of associate members, is viewed as an instrument of stability. The agreement ensures that Romania would suffer significantly if it became directly involved in the dispute in Moldova. As Romanian Foreign Minister Teodor Melescanu stated, the association agreement has begun "a new stage in [Romanian] foreign policy" (Ionescu 1993, 33).

\section{Conclusion}

The association agreement signed by Romania in February, 1993 marks a significant event in the history of the country. The agreement is seen by the EC and Romanian officials as an instrument of reform in the country. As part of the agreement, democratic and economic reform must continue in order for Romania to maintain its status and eventually achieve full membership. The larger meaning of this agreement is that a democratic and economically viable Romania will provide a measure of stability in a volatile region. Whereas EC foreign policy vis-à-vis the former Yugoslavia has proven unable to resolve conflict, perhaps a pre-emptive policy designed to provide economic security to countries in this region might prove more successful.

The admission criteria used to evaluate Romania's applications are based largely upon the criteria developed during the second enlargement. ${ }^{10}$ The political, economic and foreign policy concerns of the EC have not changed substantially over the past 15 years. The arguments made for the integration of Greece, Spain and Portugal at the time of the second enlargement also have been made by Romanian and EC officials. What the admission of Romania indicates is that, perhaps for security as well as economic 
reasons, the EC slowly is becoming a pan-European organization. If this is the case and this trend continues for the next decade, we should not be surprised to see the countries of East Europe becoming full members of the EC. The question should not be whether Romania will gain full membership in the EC, but rather how long will the process take. The answer to that question ultimately lies in the political and economic courage of Romania's leaders and citizens.

\section{NOTES}

${ }^{1}$ Poland, Hungary and the former Czechoslovakia signed their association agreements in 1991. The new association agreement with the Czech Republic and Slovakia should be signed by December 1993.

${ }^{2}$ For a discussion of this issue see Redston (1983, 207-212). In addition, see Mulligan (1977, 3-6), who argues that the foreign ministers of the EC agreed that the political importance of helping these fledgling democracies outweighed the economic problems.

${ }^{3}$ In 1980, a member of the European Parliament asked the Council of Europe how it would ensure that democratic rights would be extended in the countries seeking membership. The reply was that "the Council is convinced that the States applying for accession to the European Communities are aware of the principles underlying the Treaties and the obligations deriving therefrom" (Schloh $1980,395)$.

${ }^{4}$ Mulligan $(1977,4)$ notes that "farms of less than five hectares account for two-thirds of output in Mediterranean regions, against only one-third for the whole of the Community. And whereas the number of small farms is dropping by 4 per cent in northern parts of the Community, it is only dropping by 2 per cent in Mediterranean regions."

${ }^{5}$ For a complete discussion of the dispute between Greece and Turkey and its implications for the EC, see Kohlhase (1978, 127-134) and Tsakaloyannis (1980, 33-54).

${ }^{6}$ by 1990, Turkey, Austria, Cyprus and Malta had applied for membership in the EC. Since 1991. Sweden, the former Czechoslovakia, Hungary, Poland, Romania and Bulgaria have applied for membership. For a general discussion of the issues involved in the current and future enlargement of the EC, see Yesilada (1992).

${ }^{7}$ A run-off election for president was held on 11 October 1992. The run-off was between President Iliescu (DNSF) and Emil Constantinescu (DCR). President Iliescu won over 62 percent of the vote in the run-off election.

${ }^{8}$ At the National Salvation Front Party Congress in March, 1992, a split occurred in the leadership. President Iliescu left the Congress to form the Democratic National Salvation Front and former Prime Minister Petre Roman became the leader of the National Salvation Front. During the summer of 1993. the Democratic National Salvation Front renamed itself the Party of Social Democracy. For more discussion on the split of the party. see Ionescu (1992).

The reunification of Romania with Moldova presents another possible minority problem. Representatives of the Council of Europe are concerned about the rights of non-Romanian minorities in Moldova following possible reunification. While an understandable concern. most of the evidence indicates that Romania and Moldova will not unite in the near future. For more discussion on this issue see Socor (1992, 27-33).

${ }^{10}$ The criteria used during the admission process of the former Czechoslovakia. Hungary and Poland also seem to be essentially the same as those used during the second enlargement. For a discussion of the issues involved in the admission of these countries, see de Weydenthal(1992). 


\section{REFERENCES}

Angelis, Ivan. 1991. East-West Economic Relations Under the Aspect of Changes in the CMEA. In Peter Havlik, ed., Dismantling the Command Economy in Eastern Europe. Boulder. CO: Westview Press.

Barber, Benjamin. 1984. Strong Democracy. Berkeley: University of California Press.

Bulletin of the European Communities. 1978. 5: 7-10.

1976 Supplement. 2: 7-11.

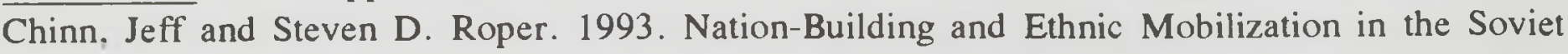
Successor States: The Case of Moldova. University of Missouri-St. Louis Center for International Studies, Occasional Papers No. 9301.

Dahl, Robert A. 1970. After the Revolution? New Haven: Yale University Press.

Economic Bulletin for Europe. 1991. New York: United Nations Publications.

Gorst, Isabel. 1990. Energy After the Wall. The Petroleum Economist 57: 19-22.

Granell, Francisco. 1978. Long Road to the EEC. The Banker 128: 65-70.

Griffith. William E. 1989. Central and Eastern Europe: The Global Context. In William E. Griffith. ed., Central and Eastern Europe: The Opening of the Curtain. Boulder. CO: Westview Press. International Year Book and Statemen's Who's Who-1990. The. 1990. West Sussex: Reed Information Service Ltd.

Ionescu, Dan. 1993. Romania Signs Association Accord with the EC. RFE/RL Research Report (5 March): 33-37.

1992. Romania's Ruling Party Splits after Congress. RFE/RL Research Report (17 April): 8-12.

Kohlhase, Norbert. 1978. The Greco-Turkish Conflict from a European Community Perspective. The World Today 15: 27-134.

Macpherson, C.B. 1977. The Life and Times of Liberal Democracy. Oxford: Oxford University Press.

Monitorul Oficial al Romaniei. 1992. Privind Constituirea Comisiei Interparlamentare BucrestiChisinau (4 December): 1-2.

Mulligan, Stephen. 1977. The 'Nine' Ponder Enlargement. European Community (September/October): 3-6.

Oppenheim, Felix E. 1971. Democracy: Characteristics Included and Excluded. The Monist 55: 2950.

Overturf, Stephen F. 1992. Forcing the Integration of Europe. National Forum 72: 26-28.

Pesmazoglu, John. 1977. A 'Special Case' for EC Membership. European Community (September/October): 7-9.

Pollis, Adamantia. 1983. The Southern European Semiperiphery and the European Community. In Carl F. Pinkele and Adamantia Pollis. eds., The Contemporary Mediterranean World. New York: Praeger.

Redston, C.J. 1983. The Impact of EC Membership on Portugal and Spain. Intereconomics (September/October): 207-212.

Remington, Robin Alison. 1992. Contradictions on the Road to Democracy and the Market in East Central Europe. Midsouth Political Science Journal 13: 3-25.

Roskin, Michael G. 1991. The Rebirth of East Furope. Englewood Cliffs, NJ: Prentice-Hall.

Schloh. Bernhard. 1980. The Accession of Greece to the European Communities. Georgia Journal of International and Comparative Law 10: 385-409.

Schumpeter, Joseph. 1943. Capitalism, Socialism and Democracy. London: Allen and Unwin.

Shafir, Michael. 1992a. Romania's Elections: Why the Democratic Convention Lost. RFE/RL Research Reports (30 October): 1-7.

1992b. Establishing the Rule of Law in Romania. RFE/RL Research Reports (3 July): 
1992c. Romanian Local Elections Herald New Political Map. RFE/RL Research Reports (13 March): 24-31.

1991. Promises and Reality. Radio Free Europe: Report on Eastern Europe (4 January): $32-37$.

Smith. Dale L. and Jurgen Wanke. 1993. Completing the Single European Market: An Analysis of the Impact on Member States. American Journal of Political Science 37: 529-554.

Sobell, Vlad. 1991. East European Integration: The Disbanding of the CMEA. EIU European Trends 1: 74-79.

Socor, Vladimir. 1992. Why Moldova Does Not Seek Reunification with Romania. RFE/RL Research Reports (31 January): 27-33.

Swann, Dennis. 1984. The Economics of the Common Market, fifth ed. London: Penguin Books.

Tsakaloyannis, Panos. 1980. The European Community and the Greek-Turkish Dispute. Journal of Common Market Studies 19: 35-54.

Wallace. William. 1990. The Transformation of Western Europe. New York: Council on Foreign Relations Press.

Weydenthal de, Jan B. 1992. Czechoslovakia. Hungary, and Poland Gain Associate Membership in the EC. RFE/RL Research Reports (7 February): 24-26.

Yesilada, Birol. 1992. Further Enlargement of the European Community. National Forum 72: 21 25.

Zidaru-Barbulescu, Aurel. 1993. Romania Seeks Admission to the Council of Europe. RFE/RL Research Reports (8 January): 11-16. 